\title{
Distribution of the epiphytic organisms on Posidonia australis and $P$. sinuosa, two seagrasses with differing leaf morphology
}

\author{
Donelle A. Trautman, Michael A. Borowitzka*
}

School of Biological Sciences \& Biotechnology, Murdoch University, Murdoch, Western Australia 6150, Australia

\begin{abstract}
The distribution of epiphytic algae and sessile invertebrates on the leaves of the seagrasses Posidonia australis Hooker $f$. and $P$. sinuosa Cambridge and Kuo is not random. Epiphyte load on the leaves of both species increases with increasing distance away from the basal meristem. There are approximately 3 times as many epiphytic algal species as invertebrate species, and many of these epiphytes grow at distinct locations on the leaves. Epiphytic invertebrates were found primarily on the basal sections of the leaves, whereas algae were most abundant near the leaf apex. Distribution of epiphyte load across the leaf surface was also non-random, with initial settlement of epiphyte propagules occurring at the margins of the leaves. The structure of the epiphytic community is strongly correlated with leaf age, with a greater abundance of epiphytic species occurring on the older leaves. It is clear that leaf morphology also plays a significant role in the distribution of the epiphytes. There is no apparent difference in the epiphytic community between the sides of the flat $P$. australis leaf whereas, in $P$. sinuosa, the concave side of the curved leaf supports a more diverse epiphytic community than the convex side. Similar patterns in the distribution of epiphytic organisms were observed on artificial seagrass leaves, indicating that, although a temporal component is involved, epiphyte distribution is influenced mainly by the relative position upon the leaf surface as well as leaf morphology, which affects the water flow pattern over the leaf.
\end{abstract}

KEY WORDS: Algae - Invertebrates - Artificial leaves - Water flow

\section{INTRODUCTION}

The seagrasses Posidonia australis Hooker $f$. and $P$. sinuosa Cambridge and Kuo are widely distributed in marine embayments and nearshore areas around the temperate coastline of Australia. P. australis occurs from Shark Bay in the north of Western Australia, around the southern coastline, northwards to Port Macquarie in New South Wales, and along the northern coast of Tasmania. $P$. sinuosa has a similar geographic range in Western Australia, but does not extend further east than Kingston in South Australia.

Both Posidonia species have long, strap-shaped leaves but are easily distinguished by differences in leaf morphology; $P$. sinuosa has a narrow, 4 to $9 \mathrm{~mm}$ wide leaf which is slightly curved in cross section,

- Addressee for correspondence

E-mail: borowitz@possum.murdoch.edu.au whereas the leaves of $P$. australis are 10 to $15 \mathrm{~mm}$ wide are flat in cross section, and are approximately twice as thick as those of P. sinuosa (Cambridge \& Kuo 1979). These leaves are an excellent substratum for the attachment of a wide variety of algae, sessile invertebrates and various microscopic and macroscopic organisms (Novak 1984, Pansini \& Pronzato 1985 Borowitzka \& Lethbridge 1989, Kendrick \& Burt 1997).

The diversity of epiphytic algae ${ }^{1}$ on seagrass leaves can be very great and may comprise a major portion of the species present in a given area (Ballantine \& Humm 1975, Harlin 1980, Borowitzka et al. 1990). The epiphytic algal biomass on Posidonia and Amphibolis is often comparable to that of the seagrasses themselves and the epiphytic component of a seagrass com-

\footnotetext{
${ }^{1}$ For the purpose of this paper, an epiphyte is defined as 'any organism that lives upon a plant whether or not a nutritional relationship exists' (Harlin 1980)
} 
munity may contribute significantly to community productivity (e.g. Penhale 1977, Bulthuis \& Woelkerling 1983, Borum et al. 1984, Heijs 1984, Mazella \& Alberte 1986, Moncreiff et al. 1992). Furthermore, calcareous epiphytes contribute to sediment production, leading to the formation of extensive sediment banks such as those found in Shark Bay, Western Australia, and help to reduce beach erosion (Walker \& Woelkerling 1988). Changes in the abundance and composition of epiphytic organisms can also be used as sensitive indicators of water quality (May 1982, Cambridge et al. 1986).

The diversity of epiphytes on seagrasses has been well documented (e.g. Humm 1964, May et al. 1978, Harlin 1980, Heijs 1985a), but much of this literature has concentrated on the taxonomy of these organisms, rather than the pattern of epiphyte distribution or the underlying causes for these patterns (e.g. Cattaneo \& Kalff 1979, Horner 1987, Lethbridge et al. 1988, Borowitzka et al. 1990, Kendrick \& Burt 1997).

The seagrass leaf is an excellent habitat for epiphytic organisms, especially algae, for several reasons: (1) settlement at the apex of the leaves exposes epiphytic algae to higher light intensities and less sedimentation compared with those growing further down the leaf, and (2) the leaf's physical movement through the water also exposes the epiphytic algae to a much greater nutrient supply and washes away any inhibitory substances (Harlin 1975, Cattaneo \& Kalff 1979, Keough 1986, Borowitzka \& Lethbridge 1989).

This paper compares the spatial and temporal distribution of epiphytic organisms on the leaves of the seagrasses Posidonia sinuosa and P. australis with related, but different, leaf morphologies and considers how abiotic factors, such as water flow and irradiance, and biotic factors, such as settlement, recruitment and growth habit, may affect the distribution of the epiphytic organisms observed.

\section{MATERIALS AND METHODS}

This study was carried out near Perth, Western Australia, in Shoalwater Bay, south of Point Peron, about halfway between Bird Island and the mainland (approximately $125^{\circ} 41^{\prime} 27^{\prime \prime} \mathrm{E}, 32^{\circ} 17^{\prime} 36^{\prime \prime} \mathrm{S}$ ). This site has extensive Posidonia meadows with monospecific stands of both $P$. sinuosa and $P$. australis growing adjacent to each other at a depth of approximately 1 to $2 \mathrm{~m}$.

For the determination of the spatial and temporal distribution and relative abundance of epiphytic organisms on the leaves, random samples of Posidonia sinuosa and $P$. australis were collected from the study site on 15 March (late summer) and on 6 August 1990 (late winter). Leaf clusters of both species were col- lected by digging around the base of the leaves and pulling out the shoots from below substratum level, so that the leaves remained attached to a small intact piece of rhizome. This kept leaf clusters intact and allowed the relative age of leaves within each cluster to be determined. Material collected from the field was frozen at $-20^{\circ} \mathrm{C}$ until analysis.

Apico-basal distribution of epiphytic organisms. For detailed analysis of epiphyte abundance and distribution on the seagrass leaves, 20 leaf clusters of each species were selected at random and the leaves in each cluster classified according to age. The shortest, and therefore youngest, leaf was designated Leaf 1, and the other leaves were numbered sequentially. Each cluster generally had 2 or 3 leaves. The leaves were cut from the shoot at the point of emergence at the top of the leaf sheath and divided into 3 equal divisions representing the apical, middle and basal sections of the leaf.

Each side of the leaf was analysed separately. The 2 sides of Posidonia sinuosa were easily distinguished as one is concave and the other is convex. The flat leaf of $P$. australis was marked to ensure that all leaves were examined in the same orientation. Epiphytic organisms discernable under the dissecting microscope were identified as far as possible (complete identification was sometimes impossible due to the immaturity of the epiphyte) and recorded along with a measure of their abundance. Due to taxonomic difficulties with the very small Bryozoa and sponges, these were not identified to genus level. Reference specimens are held in the Murdoch University herbarium (MURU).

Algal epiphyte abundance was estimated as percent cover, since most of the algae were too small for accurate dry weight measurements. The percent cover of the algal epiphytes was recorded according to the following scale: 0 (absent), $1(<5 \%), 2(5-20 \%), 3$ $(20-50 \%), 4(50-80 \%)$ or $5(>80 \%)$ cover

The epiphytic fauna occurred as distinct individuals and, in most cases, was quantified simply by counting the number of individuals present. The abundance of hydrozoans was obtained by counting the number of erect colonies emerging from the stolon, while bryozoans, which often covered larger sections of the leaf surface, were quantified in the same manner as the algae (Borowitzka et al. 1990).

The results were examined by chi square analysis (Kershaw 1973) and by a 2 -way indicator species classification (TWINSPAN), a divisive hierarchical 2-way indicator species analysis (Hill 1979).

Microscopic epiphytes were examined semi-quantitatively by scanning electron microscopy (SEM). For SEM $5 \mathrm{~mm}$ sections of the apical, middle and basal parts of a leaf were fixed in $3 \%$ glutaraldehyde in seawater for $1 \mathrm{~h}$ and then dehydrated through a graded 
series of ethanol for $15 \mathrm{~min}$ at each step before being transferred into $100 \%$ amyl acetate. After critical point drying, the samples were mounted on aluminium stubs and sputter coated with gold before examination in the SEM.

Across-leaf distribution of epiphytic organisms. To determine the distribution of epiphytic organisms across the leaf surface from margin to margin, a piece of a clear plastic marked in $1 \mathrm{~mm}$ intervals was laid across the leaf surface at right angles to the leaf margin and the percent cover of epiphytic organisms within each millimetre section was estimated to the nearest $25 \%$ under a dissecting microscope. Five leaves from each species were randomly selected and 3 replicate analyses were performed on each side of each section of the leaves.

Artificial seagrass leaves. Artificial seagrass leaves modelling both Posidonia species were constructed and deployed in the natural seagrass meadow to determine the time course of settlement, recruitment and subsequent growth phases of the epiphytic organisms in relation to the life span of the seagrass leaves. Artificial leaves modelling $P$, australis were made from $12 \mathrm{~mm}$ wide, green, rough-surfaced plastic flagging tape (Horner 1987, Lethbridge et al. 1988). A second model was made by cutting $10 \mathrm{~mm}$ wide strips from thin tinted PVC sheets. To model the curved leaves of $P$. sinuosa, a PVC garden soaker hose was cut into $35 \mathrm{~cm}$ long sections, and each of these was then cut longitudinally into six $8 \mathrm{~mm}$ wide, $1 \mathrm{~mm}$ thick strips. These artificial leaves were a little more strongly curved and stiffer than the natural leaves. A second model of $P$. sinuosa leaves was made using the PVC sheets, creating a curve in the plastic by bending it around the heating element of a plastic bag sealer.

One hundred artificial leaves of each type were attached to a rectangular $50 \times 100 \mathrm{~cm}$ epoxy-coated steel frame, to which a $20 \times 20 \mathrm{~mm}$ plastic mesh had been attached. Each type of artificial leaf was attached to the plastic mesh in clusters of 2 leaves, with the leaves arranged at an average density of 715 leaves $\mathrm{m}^{-2}$ (similar to the field density). The frame containing the artificial seagrasses was placed in a shallow bed of Posidonia sinuosa at the Bird Island study site at approximately $1.0 \mathrm{~m}$ depth on 12 June 1990 . After $45 \mathrm{~d}$, the artificial leaves were harvested and analysed in the same manner as the natural leaves.

Leaf orientation and curvature. The in situ orientation of the leaves of the 2 species in relation to the substrate was measured using a protractor which had a spirit level glued along the horizontal base line. A length of string with a table tennis ball threaded onto the end was attached to the point of origin of the protractor so that when the protractor was held level under water the string would be oriented along the line of $90^{\circ}$. The range of bending of each species of seagrass could thus be determined.

The degree of leaf curvature of Posidonia sinuosa was also determined by cutting free-hand transverse sections of the leaf at $5 \mathrm{~cm}$ intervals up the length of the leaf. These leaf sections were then stood on their cut surfaces and photocopied. Using a dissecting microscope, curvature of these sections was determined by drawing a line from one leaf margin to the other, determining the mid point of this line and measuring the perpendicular distance from this point to the concave surface of the leaf.

Water flow. The pattern of water flow over individual leaves of both Posidonia species was examined in the laboratory using a $1.5 \mathrm{~m}$ long, $25 \times 40 \mathrm{~cm}$ Perspex recirculating flume. Water was circulated around the flume at a velocity of approximately $3.5 \mathrm{~cm} \mathrm{~s}^{-1}$. Flow patterns over the leaves were visualised by the use of red food dye dissolved in seawater which was released just above the surface of the leaf at a constant and controlled rate. Movement and dispersion of the dye was analysed over both sides of the leaf of both species.

In the field, fluorescein dye was used to establish differences in the movement of water over Posidonia meadows. Release of dye over and within the meadows was monitored visually and by underwater video which allowed water flow patterns to be determined.

\section{RESULTS}

\section{Epiphyte distribution}

During this study a total of 28 species of epiphytic algae and 8 species of epiphytic invertebrates (other than molluscs) were found on the leaves of Posidonia australis, while 37 epiphytic algal and 11 invertebrate species were found on the leaves of $P$. sinuosa. The distribution of epiphytic organisms on the seagrass leaves was not random

The epiphytic organisms on the Posidonia leaves showed clear apico-basal zonation. The majority of the epiphytes, in particular the algae, were found on the apical portion of the leaves (Tables 1 to 4 ), which also had a higher total percent cover (see Fig. 3). This trend was evident throughout the year, although it was less obvious during winter when the number of species of epiphytic algae declined by almost $50 \%$. The number of species of epiphytic invertebrates remained comparatively constant throughout this study. Hydrozoans were most abundant on the leaves of $P$. australis, with Plumularia compressa found on all leaves, with the highest abundance at the base of the leaves. Plumularia nodosa was found only in the winter samples and 
Table 1. Posidonia australis. Distribution and abundance of epiphytic algae and invertebrates on the apical, middle and basal sections of leaves collected on $15 \mathrm{March} 1990$. Data is the average of the leaves from 20 leaf clusters. Abundances of algae are given on the following scale: $1(<5 \%), 2(5-20 \%), 3(20-50 \%), 4(50-80 \%), 5(>80 \%)$ cover. Bryozoans are quantified in the same way as algae, whereas invertebrate abundances are given as either number of individuals per leaf section or, in the case of hydrozoans, as the number of erect colonies emereing from the stolon. \%: percentage of leaves the epiphytic species was observed on; a: abaxial side of leaf; b: adaxial side of leaf

\begin{tabular}{|c|c|c|c|c|c|c|c|c|c|c|c|c|c|c|c|c|c|c|c|c|c|}
\hline & \multicolumn{7}{|c|}{ Leaf 1} & \multicolumn{7}{|c|}{ Leaf 2} & \multicolumn{7}{|c|}{ Leaf 3} \\
\hline & \multirow[b]{2}{*}{$\%$} & \multicolumn{2}{|c|}{ Apex } & \multicolumn{2}{|c|}{ Middle } & \multicolumn{2}{|c|}{ Base } & \multirow[b]{2}{*}{$\%$} & \multicolumn{2}{|c|}{ Apex } & \multicolumn{2}{|c|}{ Middle } & \multicolumn{2}{|c|}{ Base } & \multirow[b]{2}{*}{$\%$} & \multicolumn{2}{|c|}{ Apex } & \multicolumn{2}{|c|}{ Middle } & \multicolumn{2}{|c|}{ Base } \\
\hline & & a & $\mathrm{b}$ & a & $\mathrm{b}$ & a & $\mathrm{b}$ & & $a^{a}$ & $\mathrm{~b}$ & a & b & a & $b$ & & a & $\mathrm{b}$ & $\mathrm{a}$ & $\mathrm{b}$ & & b \\
\hline \multicolumn{22}{|l|}{ ALGAE } \\
\hline Fosliella-Pneophyllum & 29 & 1 & 1 & 1 & 1 & & & 95 & 2 & 2 & 2 & 2 & 1 & 1 & 100 & 5 & 5 & 3 & 3 & 1 & 1 \\
\hline Centroceras clavulatum & 29 & 1 & & 1 & & & & 30 & 1 & 1 & 1 & 1 & 1 & 1 & 40 & 1 & 1 & 1 & 1 & 1 & 1 \\
\hline Laurencia filiformis & 0 & & & & & & & 45 & 1 & 1 & 1 & 1 & & 1 & 90 & 1 & 1 & 1 & 1 & 1 & 1 \\
\hline Ceramium puberulum & 0 & & & & & & & 45 & 1 & 1 & 1 & 1 & 1 & 1 & 85 & 1 & 1 & 1 & 1 & 1 & 1 \\
\hline Entocladia sp. & 0 & & & & & & & 30 & 1 & 2 & 1 & 1 & 1 & & 70 & 2 & 2 & 1 & 1 & 1 & 1 \\
\hline Jania sp. & 0 & & & & & & & 20 & 1 & 1 & 1 & 1. & & & 70 & 1 & 1 & 1 & 1 & & 1 \\
\hline Polycerea nigrescens & 0 & & & & & & & 35 & 1 & 1 & 1 & 1 & & & 65 & 1 & 1 & 1 & 1 & & \\
\hline Sphacelaria rigidula & 0 & & & & & & & 10 & 1 & & & 1 & & & 60 & 1 & 1 & 1 & 1 & 1 & 1 \\
\hline Ceramium isogonum & 0 & & & & & & & 15 & 1 & & 1 & 1 & & & 50 & 1 & 1 & 1 & 1 & & \\
\hline Champia zostericola & 0 & & & & & & & 15 & $\mathrm{i}$ & $i$ & & & & & 45 & 1 & $\mathrm{i}$ & i & i & & \\
\hline Giffordia sandriana & 0 & & & & & & & 5 & 1 & & & & & & 40 & 1 & 1 & & 2 & & \\
\hline Ceramium shepherdii & 0 & & & & & & & 10 & 1 & & & & & & 35 & 1 & 1 & 1 & 1 & & \\
\hline Mychodea gracilaria & 0 & & & & & & & 10 & & 1 & & 1 & & & 35 & 1 & 1 & 1 & & & \\
\hline Johannesbaptista pellucida & 0 & & & & & & & 5 & & 1 & & & & & 35 & & & 1 & 1 & 1 & \\
\hline Audouinella sp. & 0 & & & & & & & 5 & & & 1 & & & & 30 & 1 & 1 & 1 & 1 & & \\
\hline Chondria sp. & 0 & & & & & & & 0 & & & & & & & 30 & 1 & 1 & 1 & & & \\
\hline Laurencia cruciata & 0 & & & & & & & 0 & & & & & & & 30 & 1 & 1 & 1 & & & \\
\hline Polysiphonia sp. & 0 & & & & & & & 0 & & & & & & & 25 & 1 & 1 & 1 & & & 1 \\
\hline Calothrix sp. & 0 & & & & & & & 0 & & & & & & & 20 & & & & & 1 & \\
\hline Cladophora sp. & 0 & & & & & & & 15 & 1 & & 1 & & & & 10 & 1 & 1 & & & & \\
\hline Dasya sp. & 0 & & & & & & & 0 & & & & & & & 10 & 1 & & 1 & & & \\
\hline Antithamnion verticale & 0 & & & & & & & 0 & & & & & & & 5 & & & 1 & & & \\
\hline Metagoniolithon chara & 0 & & & & & & & 0 & & & & & & & 5 & 1 & & & & & \\
\hline Enteromorpha sp. & 0 & & & & & & & 5 & & & & 1 & & & 0 & & & & & & \\
\hline \multicolumn{22}{|l|}{ INVERTEBRATES } \\
\hline Spirorbis sp. & 71 & 2 & 3 & 1 & 1 & 1 & & 100 & 5 & 15 & 10 & 7 & 6 & 2 & 100 & 15 & 8 & 9 & 10 & 6 & 6 \\
\hline Plumularia compressa & 43 & 4 & 2 & 1 & & 6 & & 50 & 7 & 12 & 9 & 11 & 10 & 15 & 70 & 8 & 6 & 13 & 12 & 11 & 22 \\
\hline Foraminiferan 1 & & & & & & & & 40 & 1 & 1 & 2 & 1 & 2 & 2 & 60 & 2 & 1 & 1 & 1 & 2 & 2 \\
\hline Bryozoan 1 & & & & & & & & 25 & 1 & 1 & 2 & 1 & & 1 & 60 & 1 & 1 & 1 & 1 & 1 & 1 \\
\hline Bryozoan 2 & & & & & & & & 15 & 1 & 1 & & & & & 50 & 1 & & 1 & 1 & 1 & 1 \\
\hline Foraminiferan 2 & & & & & & & & 10 & & & & & 1 & 1 & 30 & & 2 & 1 & 1 & 1 & 1 \\
\hline Porifera 1 & & & & & & & & & & & & & & & 15 & 1 & 1 & 1 & 1 & & 1 \\
\hline
\end{tabular}

was also concentrated on the basal sections of the leaves.

The number of epiphytic species and their relative cover varied significantly between the apical, middle and basal sections in the March samples, whereas during winter (August), only the apical and basal sections differed significantly $\left(\chi^{2}\right.$ test, $\left.p>0.05\right)$. At no stage during the study was any significant difference detected between the 2 sides of the leaves of Posidonia australis. In contrast, a highly significant difference $\left(\chi^{2}\right.$ test, $\mathrm{p}>$ $0.01)$ was found in the number and distribution of epiphytic organisms between the 2 sides of the leaves of $P$. sinuosa in late summer; however, there was no difference during winter. More species of epiphytic algae and invertebrates were encountered on the concave leaf surface (33 algal and 10 invertebrate species) than on the convex surface $(25$ aigal and 9 invertebrate species) (Tables $3 \& 4$ ).

A number of the algal species recorded on Posidonia sinuosa occurred only on the concave side of the leaf. These included Antithamnion verticale (Harvey) J. Agardh, 2 species of Crouania, Cladophora sp. 2, Herposiphonia sp., Jania sp., Polysiphonia sp. 2, Spyridia filamentosa (Wulfen) Harvey, Ulva australis Areschoug., Hincksia sp., and the colonial diatom Licmophora sp. (Tables 3 \& 4). Invertebrate epiphytes found only on the concave leaf surface were Porifera 1 and Plumularia compressa Bale (Tables 3 \& 4). Far fewer species were restricted to the convex surface. These were the red algae Laurencia cruciata Harvey, Ceramium isogonum Harvey and Chondria sp., of which only a single plant of each species was recorded. 
Table 2. Posidonia australis. Average distribution and abundance of epiphytic algae and invertebrates on the apical middle and basal sections of leaves collected on 6 August 1990. Data is the average of the leaves from 20 leaf clusters. See Table 1 for details regarding abundance scale, quantification methods and \%, a and b

\begin{tabular}{|c|c|c|c|c|c|c|c|c|c|c|c|c|c|c|c|c|c|c|c|c|c|}
\hline & \multicolumn{7}{|c|}{ Leaf 1} & \multicolumn{7}{|c|}{ Leaf 2} & \multicolumn{7}{|c|}{ Leaf 3} \\
\hline & \multirow[b]{2}{*}{$\%$} & \multicolumn{2}{|c|}{ Apex } & \multicolumn{2}{|c|}{ Middle } & \multicolumn{3}{|c|}{ Base } & \multicolumn{2}{|c|}{ Apex } & \multicolumn{2}{|c|}{ Middle } & \multicolumn{2}{|c|}{ Base } & \multirow[b]{2}{*}{$\%$} & \multicolumn{2}{|c|}{ Apex } & \multicolumn{2}{|c|}{ Middle } & \multicolumn{2}{|c|}{ Base } \\
\hline & & a & $\mathrm{b}$ & $\mathrm{a}$ & $\mathrm{b}$ & a & $\mathrm{b}$ & $\%$ & a & $\mathrm{b}$ & a & b & $\mathrm{a}$ & $\mathrm{b}$ & & a & $\mathrm{b}$ & a & $\mathrm{b}$ & a & $\mathrm{b}$ \\
\hline \multicolumn{22}{|l|}{ ALGAE } \\
\hline Fosliella-Pneophyllum & 0 & & & & & & & 95 & 2 & 3 & 2 & 2 & 2 & 2 & 100 & 5 & 5 & 4 & 4 & 2 & 2 \\
\hline Ceramium puberulum & 0 & & & & & & & 25 & 1 & 1 & 1 & & & & 80 & 1 & 1 & 1 & 1 & 1 & 1 \\
\hline Entocladia sp. & 0 & & & & & & & 0 & & & & & & & 90 & 2 & 2 & 1 & 2 & 1 & \\
\hline Polycerea nigrecens & 0 & & & & & & & 0 & & & & & & & 55 & 1 & 1 & 1 & 1 & & \\
\hline Cladosiphon filum & 0 & & & & & & & 0 & & & & & & & 50 & 1 & 1 & 1 & 1 & & \\
\hline Giffordia sandriana & 0 & & & & & & & 0 & & & & & & & 20 & 1 & & 1 & & & \\
\hline Ulva australis & 0 & & & & & & & 0 & & & & & & & 15 & 1 & 1 & & & & \\
\hline Dasya sp. & 0 & & & & & & & 0 & & & & & & & 10 & 1 & 1 & & & & \\
\hline Laurencia filiformis & 0 & & & & & & & 0 & & & & & & & 10 & 1 & & & & 1 & \\
\hline Sphacelaria rigidula & 0 & & & & & & & 0 & & & & & & & 10 & 1 & 1 & & & & \\
\hline Antithamnion verticale & 0 & & & & & & & 0 & & & & & & & 5 & & & & & 1 & \\
\hline Centroceras clavulatum & 0 & & & & & & & 0 & & & & & & & 5 & & & & & & 1 \\
\hline Enteromorpha sp. & 0 & & & & & & & 0 & & & & & & & 5 & & 1 & & & & \\
\hline \multicolumn{22}{|l|}{ INVERTEBRATES } \\
\hline Plumularia compressa & 100 & 5 & & 4 & & & & 60 & 24 & 26 & 39 & 21 & 49 & 13 & 85 & 20 & 12 & 16 & 35 & 31 & 59 \\
\hline Spirorbis sp. & 0 & & & & & & & 65 & 2 & 4 & 2 & 2 & 3 & 2 & 90 & 3 & 4 & 2 & 5 & 2 & 6 \\
\hline Foraminiferan 1 & 0 & & & & & & & 55 & 2 & 2 & 1 & 2 & 4 & 1 & 80 & 1 & 1 & 2 & 2 & 2 & 3 \\
\hline Porifera 1 & 0 & & & & & & & 5 & & & & & 1 & & 5 & & & & & 1 & \\
\hline Bryozoan 1 & 0 & & & & & & & 0 & & & & & & & 25 & 1 & 1 & & 1 & & \\
\hline Plumularia nodosa & 0 & & & & & & & 0 & & & & & & & 25 & & & & 38 & 34 & 66 \\
\hline
\end{tabular}

A single compound ascidian was also found on the convex side of a $P$. sinuosa leaf. In general, most algal epiphytes growing on the convex surface were small turf-forming species.

Of the species common to both sides of the leaf of Posidonia sinuosa, variation in distribution and abundance was apparent for certain species (Tables 3 \& 4). Audouinella sp., Calothrix sp., Dasya sp., Giffordia sandriana (Zanardini in Kützing) Hamel and Porifera 2 were found on the middle and apical sections of the concave surface, but only on the apical section of the convex surface. Similarly, Ceramium shepherdii Womersley, Cladophora sp. 1 and Mychodea gracilaria (Sonder) Kraft were found along the entire length of the concave surface of the leaf, but only occursed on the middle and apical sections of the convex leaf surface. On the other hand, Centroceras clavulatum (C. Agardh) Montagne and Polysiphonia sp. 1 were observed on all sections on both sides of the leaf, but were more abundant on the concave side of the leaf. On both seagrasses the encrusting coralline algae Fosliella cymodoceae (Foslie) Jones and Woelkerling and Pneophyllum caulerpae (Foslie) Jones and Woelkerling were the most common algae, occurring along the entire length of almost all leaves examined. The cover of encrusting coralline algae increased towards the apex of the leaf, at times reaching $100 \%$ cover. Inter- estingly, SEM examination of the leaves showed that on the older leaves of $P$. sinuosa germination disks of $F$. cymodoceae and $P$. caulerpae were common on the convex surface of the leaf, whereas only mature thalli of these algae were observed on the concave side of the leaf. Other widely distributed algal species along the leaf surfaces were $C$. clavulatum, Laurencia filiformis (C. Agardh) Mertens, Sphacelaria rigidula Kützing, Ceramium puberulum Sonder, and an encrusting green alga, Entocladia sp. (Tables 1 to 4).

Other algae had a more limited distribution, being restricted to certain areas of the leaf. Many of the larger algae, including Audouinella sp., Ceramium isogonum Harvey, Champia zostericola (Harvey) Reedman and Womersley, Cladophora sp. 1, Cladosiphon filum (Harvey) Kylin, Giffordia sandriana, Mychodea gracilania (Sonder) Kraft, Polycerea nigrescens (Harvey ex Kützing) Kylin and Ulva australis Areschoug were found commonly on the middle and apical sections of the leaf of Posidonia australis but never on the basal section of this species (Tables $1 \& 2$ ).

The epiphytic invertebrates Spirorbis sp., Bryozoan 2 (= Thairopora mamillaris?) and Foraminiferan 1 were found on the leaves of both seagrass species on all sections. In Posidonia australis the hydroid Plumularia compressa and another bryozoan (Bryozoan 1 = Lichenopora sp.) were also found on all parts of the 
Table 3. Posidonia sinuosa. Distribution and abundance of epiphytic algae and invertebrates on the apical, middle and basal sections of leaves collected on 15 March 1990. Data is the average of the leaves from 20 leaf clusters. c: concave side of leaf; $v$ : convex side of leaf. See Table 1 for details regarding abundance scale, quantification methods and \%

\begin{tabular}{|c|c|c|c|c|c|c|c|c|c|c|c|c|c|c|c|c|c|c|c|c|c|}
\hline & \multicolumn{7}{|c|}{ Leaf 1} & \multicolumn{7}{|c|}{ Leaf 2} & \multicolumn{7}{|c|}{ Leaf 3} \\
\hline & \multirow[b]{2}{*}{$\%$} & \multicolumn{2}{|c|}{ Apex } & \multicolumn{2}{|c|}{ Middle } & \multicolumn{2}{|c|}{ Base } & \multirow[b]{2}{*}{$\%$} & \multicolumn{2}{|c|}{ Apex } & \multicolumn{2}{|c|}{ Middle } & \multicolumn{2}{|c|}{ Base } & \multirow[b]{2}{*}{$\%$} & \multicolumn{2}{|c|}{ Apex } & \multicolumn{2}{|c|}{ Middle } & \multicolumn{2}{|c|}{ Base } \\
\hline & & c & $\mathrm{v}$ & c & $v$ & $\mathrm{C}$ & $\mathrm{v}$ & & $\mathrm{c}$ & $\mathrm{v}$ & $\mathrm{C}$ & $\mathrm{v}$ & c & $\mathrm{v}$ & & c & v & $\mathrm{c}$ & $v$ & $c$ & v \\
\hline ALGAE & & & & & & & & & & & & & & & & & & & & & \\
\hline Fosliella-Pneophyllum & 57 & 2 & 1 & 1 & 1 & & & 83 & 2 & 1 & 1 & 1 & 1 & 1 & 100 & 5 & 4 & 3 & 2 & 1 & 1 \\
\hline Sphacelaria rigidula & 43 & & & 1 & 1 & & & 67 & 1 & 1 & 1 & 1 & 1 & & 100 & 1 & 1 & 1 & 1 & 1 & 1 \\
\hline Chaetomorphaceae & 29 & 1 & & & & & & 50 & 2 & 1 & 1 & 1 & & & 65 & 2 & 2 & 1 & 1 & & \\
\hline Centroceras clavulatum & 14 & 1 & & & & & & 56 & 1 & 1 & 1 & & 1 & & 100 & 1 & 1 & 1 & 1 & 1 & 1 \\
\hline Laurencia filiformis & 14 & & & & 1 & & & 50 & 1 & 1 & 1 & & 1 & & 95 & 1 & 1 & 1 & 1 & 1 & 1 \\
\hline Cladophora sp.1 & 0 & & & & & & & 39 & 1 & 1 & 1 & & & & 85 & 1 & 1 & 1 & 2 & 1 & \\
\hline Polysiphonia sp.1 & 0 & & & & & & & 39 & 1 & & 1 & & & 1 & 45 & 1 & 1 & 1 & 1 & 1 & \\
\hline Giffordia sandriana & 0 & & & & & & & 33 & 1 & 1 & & & & & 75 & 1 & 1 & 1 & 1 & & \\
\hline Polycerea nigrescens & 0 & & & & & & & 28 & 1 & 1 & 1 & 1 & & & 35 & 1 & 1 & 1 & 1 & & \\
\hline Ceramium puberulum & 0 & & & & & & & 22 & 1 & 1 & & & & & 80 & 1 & 1 & 1 & 1 & & 1 \\
\hline Ceramium shepherdii & 0 & & & & & & & 22 & 1 & 1 & 1 & & & & 55 & 1 & 1 & 1 & 1 & 1 & \\
\hline Dasya sp. & 0 & & & & & & & 11 & 1 & & & & & & 25 & & 1 & 1 & & & \\
\hline Champia zostericola & 0 & & & & & & & 6 & & 1 & & & & & 80 & 1 & 1 & 1. & 1 & & \\
\hline Mychodea gracilaria & 0 & & & & & & & 6 & 1 & & & & & & 70 & 1 & 1 & 1 & 1 & 1 & \\
\hline Calothrix sp. & 0 & & & & & & & 6 & & & 1 & & & & 35 & 1 & 1 & 1 & & & \\
\hline $\begin{array}{l}\text { Johannesbaptista } \\
\text { pellucida }\end{array}$ & 0 & & & & & & & 6 & 1 & & & & & & 35 & 1 & 1 & 1 & 1 & & \\
\hline Enteromorpha sp. & 0 & & & & & & & 6 & 1 & & & & & & 20 & & & 1 & & 1 & \\
\hline Crouania sp.2 & 0 & & & & & & & 6 & & & 1 & & & & 0 & & & & & & \\
\hline Jania sp. & 0 & & & & & & & 2 & 1 & & & & & & 75 & 1 & & 1 & & & \\
\hline Laurencia cruciata & 0 & & & & & & & 0 & & & & & & & 30 & & & & 1 & & \\
\hline Audouinella sp. & 0 & & & & & & & 0 & & & & & & & 25 & 1 & 1 & 1 & & & \\
\hline Cladophora sp.2 & 0 & & & & & & & 0 & & & & & & & 15 & 1 & & & & & \\
\hline Hincksia sp. & 0 & & & & & & & 0 & & & & & & & 15 & & & 1 & & 1 & \\
\hline Polysiphonia sp.3 & 0 & & & & & & & 0 & & & & & & & 15 & 1 & 1 & & 1 & & \\
\hline Polysiphonia sp.2 & 0 & & & & & & & 0 & & & & & & & 10 & & & 1 & & 1 & \\
\hline Antithamnion verticale & 0 & & & & & & & 0 & & & & & & & 5 & & & & & 1 & \\
\hline Ceramium isogonum & 0 & & & & & & & 0 & & & & & & & 5 & & 2 & & & & \\
\hline Chondria sp. & 0 & & & & & & & 0 & & & & & & & 5 & & 1 & & & & \\
\hline Crouania sp.1 & 0 & & & & & & & 0 & & & & & & & 5 & & & 1 & & & \\
\hline Herposiphonia sp. & 0 & & & & & & & 0 & & & & & & & 5 & 1 & & & & & \\
\hline Licmorpha sp. & 0 & & & & & & & 0 & & & & & & & 5 & 1 & & & & & \\
\hline Plocamium mertensii & 0 & & & & & & & 0 & & & & & & & 5 & & & 1 & & & \\
\hline Spyridia filamenlosa & 0 & & & & & & & 0 & & & & & & & 5 & 1 & & & & & \\
\hline INVERTEBRATES & & & & & & & & & & & & & & & & & & & & & \\
\hline Spirorbis sp. & 71 & 5 & 3 & 4 & 2 & 3 & 2 & 100 & 14 & 7 & 9 & 4 & 5 & 2 & 100 & 31 & 10 & 31 & 7 & 11 & 3 \\
\hline Foraminiferan 1 & 43 & 4 & 1 & 1 & & & & 61 & 3 & 2 & 1 & 1 & 1 & 2 & 80 & 3 & 3 & 3 & 2 & 5 & 2 \\
\hline Bryozoan 1 & 14 & & & & 1 & & & 33 & 1 & 1 & 1 & & & & 55 & 1 & 1 & 1 & 1 & & \\
\hline Porifera 2 & 0 & & & & & & & 28 & 1 & & & & & & 70 & 1 & 1 & 1 & & & \\
\hline Bryozoan 2 & 0 & & & & & & & 22 & & 1 & 1 & 1 & & & 45 & 1 & 1 & 1 & 1 & 1 & 1 \\
\hline Foraminiferan 2 & 0 & & & & & & & 22 & & & 1 & & 2 & 1 & 45 & 1 & 1 & 2 & 1 & 2 & 1 \\
\hline Porifera 1 & 0 & & & & & & & 11 & 1 & & 1 & & & & 50 & 1 & & 1 & & 1 & \\
\hline Compound ascidian & 0 & & & & & & & 0 & & & & & & & 5 & & & & 2 & & \\
\hline Plumularia compressa & 0 & & & & & & & 0 & & & & & & & 5 & 2 & & & & & \\
\hline
\end{tabular}

leaf, whereas they had a much more restricted distribution on $P$. sinuosa. On the other hand, a sponge, Porifera 1, which was found growing over the whole length of the concave leaf surface of $P$. sinuosa, grew only on the basal and middle sections of $P$. australis (Tables $3 \& 4$ ).

Analysis of the youngest leaves in each leaf cluster showed that the encrusting coralline algae Centro- ceros clavulatum and foraminiferans were the earliest colonisers of the leaves. SEM also showed the presence of the diatom Cocconeis sp. In Posidonia australis, Ceramium puberulum, the hydrozoans and Spirorbis sp. were also early colonisers, whereas in $P$. sinuosa they were only found on the older leaves.

The most obvious seasonal difference between late summer and late winter was the overall reduction in 
Table 4. Posidonia sinuosa. Distribution and abundance of epiphytic algae and invertebrates on the apical, middle and basal sections of leaves collected on 6 August 1990. Data is the average of the leaves from 20 leaf clusters. See Tables $1 \& 3$ for details regarding abundance scale, quantification methods and \%, $\mathrm{c}$ and $\mathrm{v}$

\begin{tabular}{|c|c|c|c|c|c|c|c|c|c|c|c|c|c|c|c|c|c|c|c|c|}
\hline & \multicolumn{7}{|c|}{ Leaf 1} & \multicolumn{7}{|c|}{ Leaf 2} & \multicolumn{6}{|c|}{ Leaf 3} \\
\hline & \multirow[b]{2}{*}{$\%$} & \multicolumn{2}{|c|}{ Apex } & \multicolumn{2}{|c|}{ Middle } & \multicolumn{2}{|c|}{ Base } & \multirow[b]{2}{*}{$\%$} & \multicolumn{2}{|c|}{ Apex } & \multicolumn{2}{|c|}{ Middle } & \multicolumn{2}{|c|}{ Base } & \multirow[b]{2}{*}{$\%$} & \multicolumn{2}{|c|}{ Apex } & \multicolumn{2}{|c|}{ Middle } & Base \\
\hline & & c & $v$ & c & $\mathrm{v}$ & C & v & & C & $\mathrm{v}$ & c & $\mathrm{v}$ & c & $v$ & & c & $v$ & c & $v$ & $\mathrm{C} \quad \mathrm{V}$ \\
\hline \multicolumn{21}{|l|}{ ALGAE } \\
\hline Fosliella-Pneophyllum & 88 & 3 & 3 & 2 & 1 & 1 & 1 & 100 & 5 & 5 & 4 & 4 & 2 & 2 & & & & & & \\
\hline Ceramium puberulum & 0 & & & & & & & 65 & 1 & 1 & 1 & 1 & & & & & & & & \\
\hline Entocladia sp. & 0 & & & & & & & 55 & 1 & 2 & 2 & 2 & & & & & & & & \\
\hline Cladosiphon filum & 0 & & & & & & & 50 & 1 & 1 & & 1 & & & & & & & & \\
\hline Laurencia filiformis & 0 & & & & & & & 40 & 1 & 1 & 1 & & 1 & & & & & & & \\
\hline Polycerea nigrescens & 0 & & & & & & & 30 & 1 & 1 & & 1 & & & & & & & & \\
\hline Giffordia sandriana & 0 & & & & & & & 25 & 1 & 1 & & & & & & & & & & \\
\hline Antithamnion verticale & 0 & & & & & & & 15 & & & 1 & & & & & & & & & \\
\hline Cladophora sp.2 & 0 & & & & & & & 15 & 1 & & & & & & & & & & & \\
\hline Sphacelaria rigidula & 0 & & & & & & & 15 & 1 & & 1 & & & & & & & & & \\
\hline Centroceras clavulatum & 0 & & & & & & & 10 & & & 1 & & & & & & & & & \\
\hline Enteromorpha sp. & 0 & & & & & & & 5 & & & 1 & & & & & & & & & \\
\hline Ulva australis & 0 & & & & & & & 5 & 1 & & & & & & & & & & & \\
\hline \multicolumn{21}{|l|}{ INVERTEBRATES } \\
\hline Spirorbis sp. & 88 & 3 & 2 & 2 & 6 & 2 & & 100 & 36 & 3 & 58 & 1 & 17 & & & & & & & \\
\hline Foraminiferan 1 & 75 & 1 & 1 & 1 & 1 & 4 & 2 & 85 & 3 & 1 & 6 & 3 & 5 & 2 & & & & & & \\
\hline Bryozoan 1 & 25 & 1 & 1 & & & & & 60 & 1 & 1 & 1 & 1 & 1 & 1 & & & & & & \\
\hline Plumularia compressa & 25 & 3 & 10 & 8 & 25 & 16 & 24 & 25 & 6 & & 36 & & 47 & 5 & & & & & & \\
\hline Campanularia australis & 12 & & & & 5 & & & 10 & & & 84 & & 115 & 12 & & & & & & \\
\hline Porifera 1 & 0 & & & & & & & 40 & 1 & & 1 & & 1 & & & & & & & \\
\hline Pycnotheca producta & 0 & & & & & & & 5 & 28 & & 115 & 53 & 122 & 117 & & & & & & \\
\hline
\end{tabular}

algal species number. The number of algal species present in winter was about half that of the late summer sample. In contrast, there was little change in the number of invertebrate species between the seasons (compare Tables $1 \& 3$ with Tables $2 \& 4$ respectively).

The epiphyte distribution was further analysed by a TWINSPAN, which also indicated that the oldest leaves differed because of their high epiphyte load and that there were also distinct seasonal differences in the epiphyte communities (Figs. 1 \& 2). The classification showed that the epiphytic communities on the 2 sides of the leaf of Posidonia australis were similar (Fig. 1), whereas the epiphyte communities on the 2 sides of the leaves of $P$. sinuosa were different, especially in summer (Fig. 2).

\section{Across-leaf distribution of epiphytes}

An analysis of the distribution and cover of epiphytic organisms across the leaf showed that the percent cover was highest at the margins and least at the centre (Fig. 3). In Posidonia australis there was no difference between the 2 sides of the leaf (Fig. 3a,b), whereas in $P$. sinuosa the margin to centre difference was less pronounced on the convex leaf surface than the concave leaf surface (Fig. 3c,d). In P. sinuosa, this leaf edge to centre difference was much more pronounced on the older leaves, especially at the leaf apex.

Analysis of both the natural and artificial leaves indicated that initial settlement of epiphytic propagules occurred near the leaf margins, with further colonisation proceeding inwards, eventually covering most of the leaf surface on older leaves. This general pattern of across-leaf epiphyte distribution was the same for leaves of all ages, except that in the older leaves the epiphyte cover at the centre of the leaf eventually reached $100 \%$.

\section{Artificial seagrass leaves}

Although the total number of epiphytic species was much reduced on the artificial leaves compared with the natural leaves, a pattern of zonation of epiphytic organisms similar to that found on natural leaves of Posidonia australis could already be observed on the artificial leaves made from plastic flagging tape after $45 \mathrm{~d}$ (Table 5A). The encrusting coralline algae Fosliella cymodoceae and Pneophyllum caulerpae, and the green alga Entocladia sp. were observed along the entire length of both sides of the artificial leaves, often covering over half the leaf surface. The blue-green 


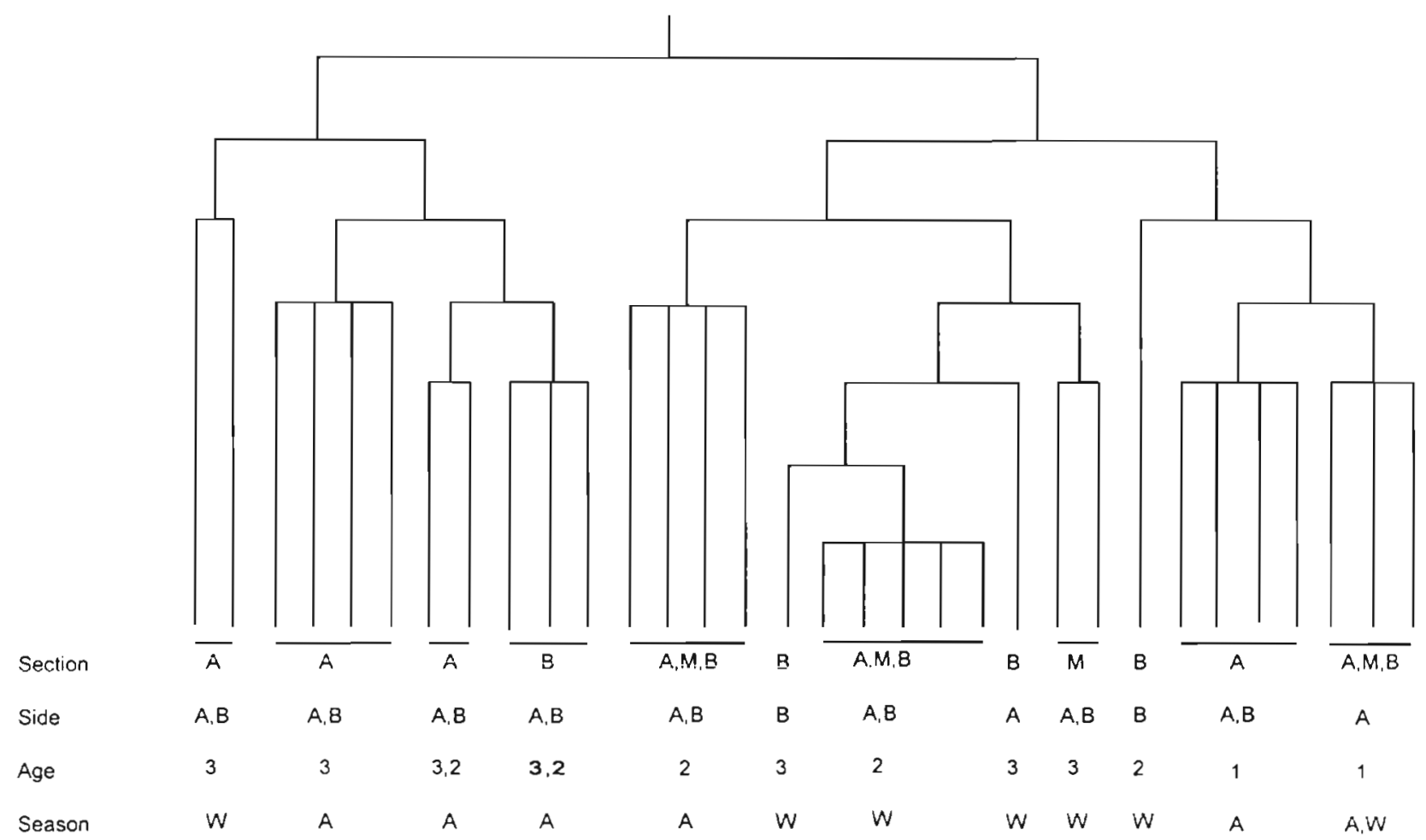

Fig. 1. Posidonia australis. TWINSPAN classification of leaves based on the organisms present. Dendrogram shows linkages only and the vertical axis does not imply any particular degree of similarity. Section: $A=$ apex, $M=$ middle, $B=$ base of leaf $;$ Side: $A=$

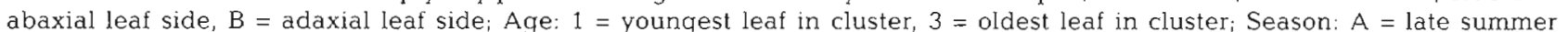
(March), $W=$ winter (August)

alga Calothrix sp. and the algae Cladosiphon filum, Sphacelaria rigidula and Ulva australis were occasionally found on the apical portions of the artificial leaves but only as single plants. Spirorbis sp. was the only invertebrate observed, and it was largely restricted to the basal sections of the leaves (Table 5A).

In contrast, the artificial leaves made from the PVC sheet modelling Posidonia australis, showed an opposite trend in the distribution of epiphyte load, with most of the 13 species observed only on the basal sections of the leaves (Table 5B). Again, the encrusting coralline algae Fosliella cymodoceae and Pneophyllum caulerpae as well as the prostrate green alga Entocladia sp. were common along the entire length of all the leaves examined, but were most abundant on the basal sections. Calothrix sp., Ceramium puberulum and a protozoan, Foraminiferan 1. were found on both sides of the leaves but restricted to the basal sections (Table 5B). All other larger algae and invertebrate species on these artificial leaves were found as single individuals on only 1 side of the basal section of 1 leaf and were not considered indicative of the sample. No significant difference $\left(\chi^{2}\right.$ test) in the numbers of epiphytic organisms was found between any of the leaf sections or between the sides of the leaves.
Both types of artificial Posidonia sinuosa leaves also tended to have an opposite distribution of epiphytic organisms from the natural leaves, with most of the epiphyte load on the basal sections rather than at the apex (compare Tables $3 \& 4$ with Table 6). Artificial $P$. sinuosa leaves made from PVC sheets displayed a slightly more widespread distribution of epiphytic organisms in comparison with the artificial leaves of $P$. australis made from the same material. In total, 10 species of epiphytic organisms were identified on these artifical $P$. sinuosa leaves; all of these were algae. The encrusting coralline algae Entocladia sp., Cladosiphon filum and Ceramium puberulum grew along the entire length of the artificial leaves, whereas all other algal species were found mainly on the basal section of the leaves and on the concave surface (Table $6 \mathrm{~A}$ ). $\chi^{2}$ analysis indicated no significant difference ( $p>0.05$ ) in epiphyte distribution between any of the leaf sections or between the sides of the leaves.

Nine epiphytic algal and 2 invertebrate species were found on the artificial leaves of Posidonia sinuosa made from. PVC hosing (Table 6B). A clear distinction in the distribution of epiphytic organisms was noted between the 2 sides of this leaf. Fosliella cymodoceae and Pneophyllum caulerpae and Entocladia sp. were recorded along the length of both sides, but were pre- 


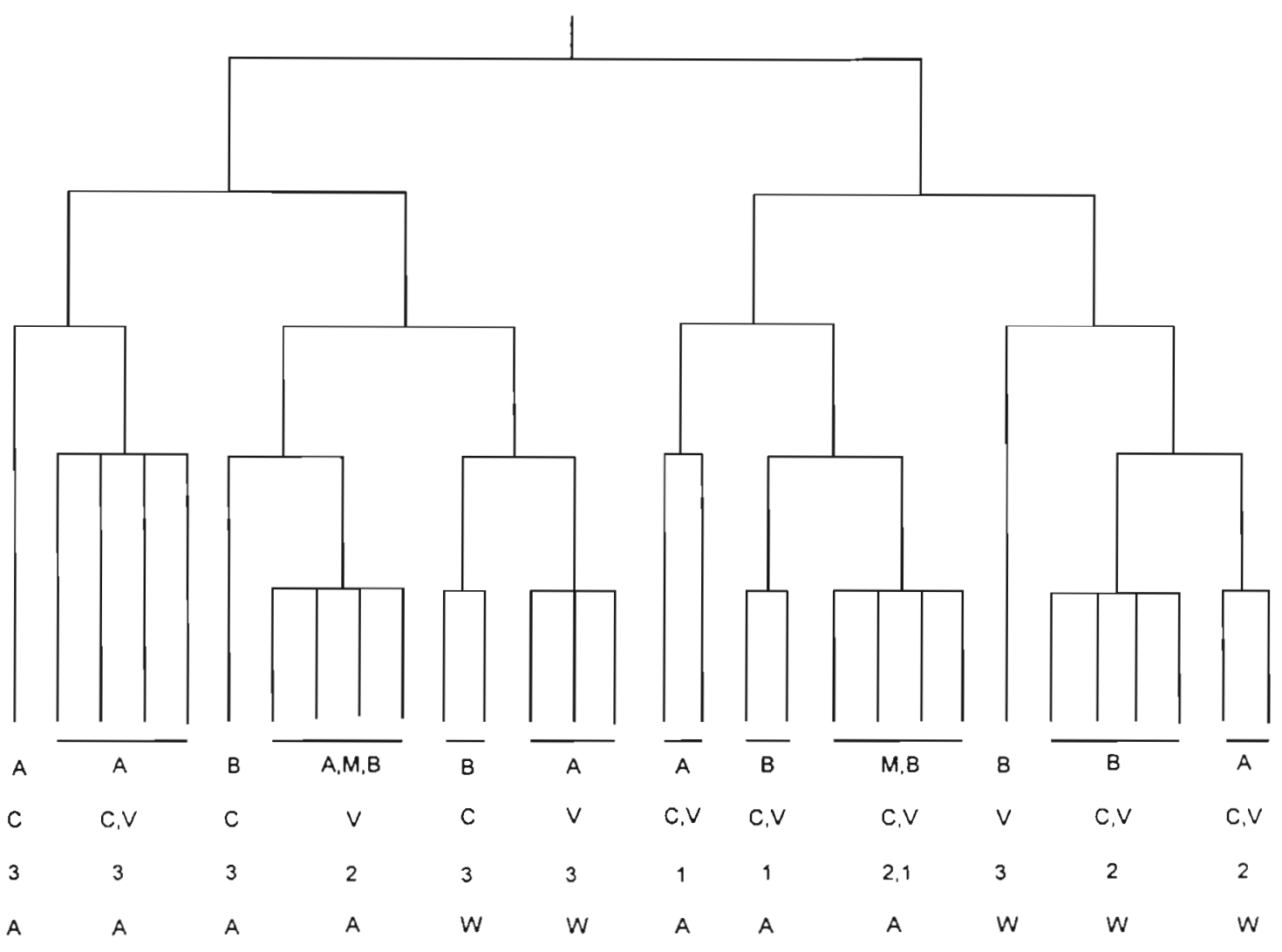

Fig. 2. Posidonia sinuosa. TWINSPAN classification of leaves based on the organisms present. Dendrogram shows linkages only and the vertical axis does not imply any particular degree of similarity. Section: $A=$ apex, $M=$ middle, $B=$ base of leaf; Side: $C=$ concave leaf side, $\mathrm{V}=$ convex leaf side; Age: 1 = youngest leaf in cluster, $3=$ oldest leaf in cluster; Season: $\mathrm{A}=$ late summer (March), $W=$ winter (August)

sent only as minute colonies on the convex surface. All other algal species grew only on the concave surface and were usually restricted to the basal sections of the leaves (Table 6). Spirorbis sp. was found only on the concave surface, primarily on the leaf apex, with a single individual also found on a basal segment. A single Foraminiferan 1 individual was found on the basal section, on the convex side of 1 leaf (Table 6 ). $\chi^{2}$ analysis showed no significant difference in the numbers of epiphytic organisms on the leaf segments or between the sides of the leaves; however, the sides of the leaves were classified into different groups by TWINSPAN.

Fig. 3. Posidonia australis, $P$. sinuosa. Percent cover of epiphytic organisms across the leaves collected in March (late summer). (a) P. australis, abaxial side of leaf; (b) $P$. australis, adaxial side of leaf; (c) P. sinuosa, concave side of

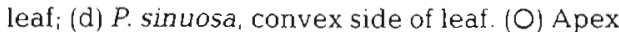
of leaf; ( $)$ middle of leaf; $(\nabla)$ base of leaf
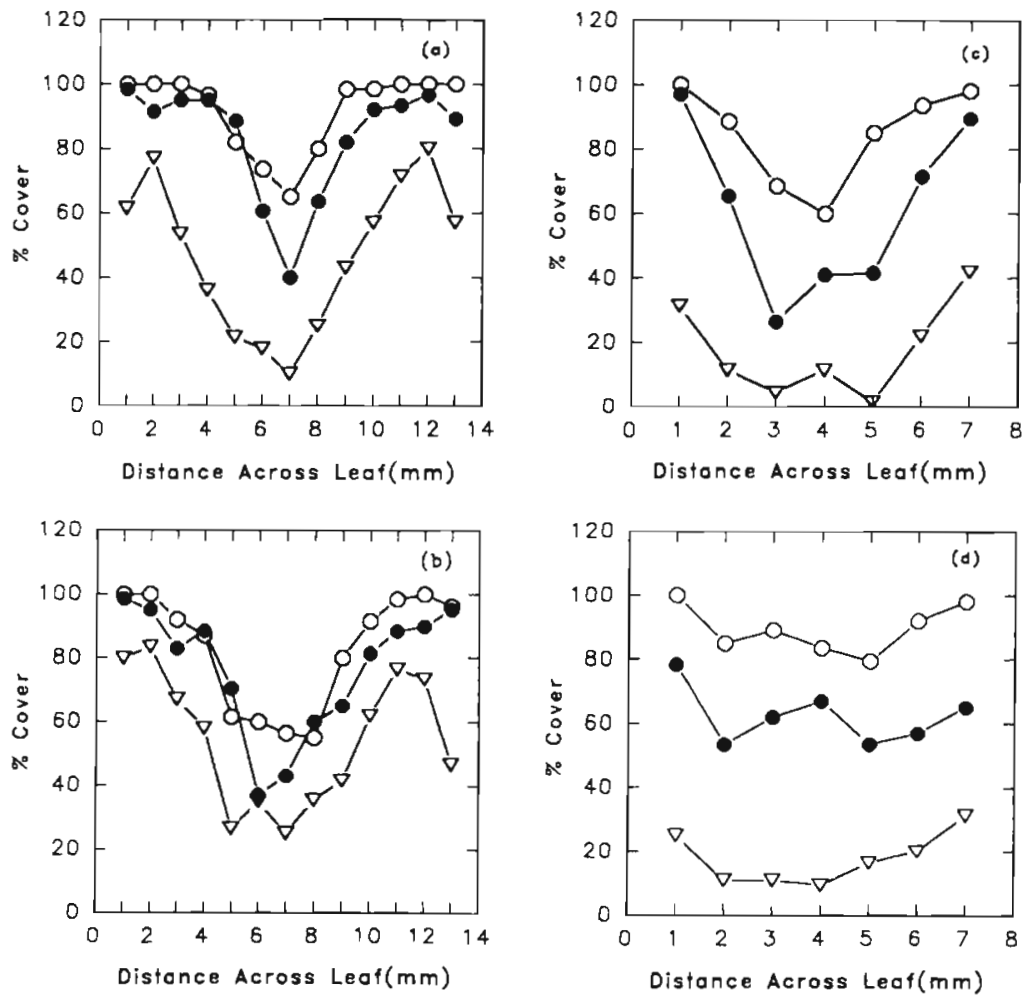
Table 5. Distribution and abundance of epiphytic organisms on artificial leaves modelling Posidonia australis after $45 \mathrm{~d}$ exposure (see Table 1 for details regarding abundance scale quantification methods and \%). Data is the average from 20 leaves. (A) Leaves made from flagging tape; (B) leaves made from PVC sheet. $a, b$ : different sides of the leaves

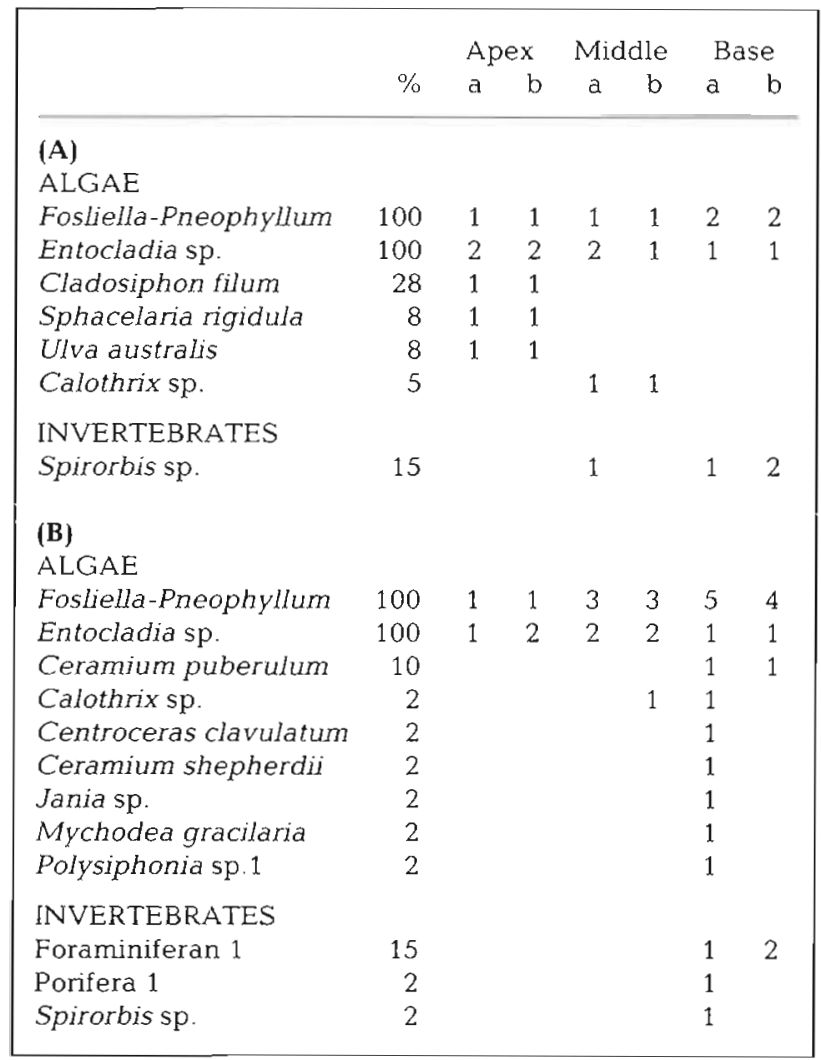

\section{In situ leaf orientation and water flow}

The leaf bases of both species of seagrass in the field are predominantly oriented along a NE-SW direction, which corresponds to the prevailing direction of water flow at this site. The way in which the seagrass leaves lie in the water column differs between the species. In still waters, Posidonia australis leaves tend to stand upright in the water column, curving over only at the leaf apex, whereas $P$. sinuosa leaves bend over at a lower point so that the leaves lie closer to the sediment. The leaves of $P$. australis emerge from the sediment at an angle of approximately $70^{\circ}$ and bend less abruptly at the tip, whereas the leaves of $P$. sinuosa emerge at an angle of 40 to $50^{\circ}$ The across-leaf curvature of $P$. sinuosa leaves varies between leaves, but increases with increasing distance from the basal meristem (Fig. 4).

Examination of the movement and dispersion of dye over individual leaves of Posidonia australis in the laboratory flow tank showed that, at low current speeds of approximately $3.5 \mathrm{~cm} \mathrm{~s}^{-1}$, water initially pools on the surface of the leaf before travelling only 1 to $2 \mathrm{~cm}$ along its length and then lifting off. Both sides of the leaf show the same flow pattern. This pattern of dispersion indicates that the leaf surface is exposed to a large volume of water. The 2 sides of the $P$. sinuosa leaves, on the other hand, showed different patterns of dispersion. On the concave surface of the leaf, the dye was effectively channelled along the entire length of the leaf, whereas on the convex side of the leaf the pattern of dispersion was similar to that observed with $P$. australis leaves, i.e. the dye was initially carried a short distance along the length of the leaf before either lifting off the surface or being deflected off the sides.

Examination of the dispersion of fluorescein dye over a Posidonia australis meadow revealed that there is little exchange between the water above and within the seagrass meadow; dye released within the meadow tended to stay within the leaf canopy for some time. In a $P$. sinuosa meadow, however, dye released within the leaf canopy had a tendency to leave the canopy rapidly and disperse out over the seagrass bed and up into the water column.

Table 6. Distribution and abundance of epiphytic organisms on artificial leaves modelling Posidonia sinuosa after $45 \mathrm{~d}$ exposure (see Table 1 for details regarding abundance scale, quantification methods and \%). (A) Leaves made from PVC sheet; (B) leaves made from plastic hosing. C: concave side of leaf, $\mathrm{v}$ : convex side of leaf

\begin{tabular}{|c|c|c|c|c|c|c|c|}
\hline & \multirow[b]{2}{*}{$\%$} & \multicolumn{2}{|c|}{ Apex } & \multicolumn{2}{|c|}{ Middle } & \multicolumn{2}{|c|}{ Base } \\
\hline & & $\mathrm{c}$ & $\mathrm{v}$ & $\mathrm{c}$ & $\mathrm{v}$ & & $\mathrm{v}$ \\
\hline \multicolumn{8}{|l|}{ (A) } \\
\hline \multicolumn{8}{|l|}{ ALGAE } \\
\hline Fosliella-Pneophyllum & 100 & 2 & 1 & 3 & 2 & 3 & 2 \\
\hline Entocladia sp. & 100 & 3 & 1 & 3 & 1 & 2 & 1 \\
\hline Ceramium puberulum & 41 & 1 & 1 & & 1 & 1 & 1 \\
\hline Cladosiphon filum & 26 & 1 & 1 & 1 & 1 & 1 & \\
\hline Laurencia filiformis & 1.8 & 1 & & & & 1 & 1 \\
\hline Centroceras clavulatum & 9 & 1 & & & & 1 & \\
\hline Ceramium shepherdii & 9 & & & & & 1 & 1 \\
\hline Jania sp. & 5 & & & & & 1 & \\
\hline Polysiphonia sp. 1 & 5 & & & & & 1 & \\
\hline \multicolumn{8}{|l|}{ (B) } \\
\hline \multicolumn{8}{|l|}{ ALGAE } \\
\hline Fosliella-Pneophyllum & 1.00 & 3 & 1 & 3 & 1 & 2 & 1 \\
\hline Entocladia sp. & 60 & 1 & 1 & 1 & 1 & 1 & 1 \\
\hline Laurencia filiformis & 10 & 1 & & 1 & & 1 & \\
\hline Cladosiphon filum & 5 & 1 & & & & 1 & \\
\hline Ceramium shepherdii & 5 & & & 1 & & & \\
\hline Antithamnion verticale & 2 & & & & & 1 & \\
\hline Sphacelaria rigidula & 2 & & & & & 1 & \\
\hline Ceramium puberulum & 2 & & & 1 & & & \\
\hline \multicolumn{8}{|l|}{ INVERTEBRATES } \\
\hline Spirorbis sp. & 10 & 1 & & & & 1 & \\
\hline Foraminiferan 1 & 2 & & & & & & 2 \\
\hline
\end{tabular}




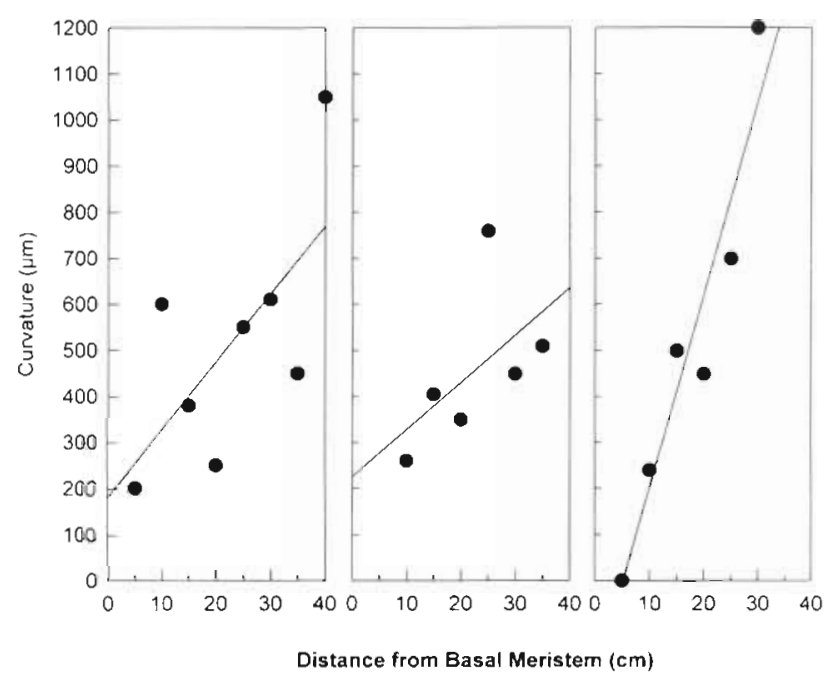

Fig. 4. Posidonia sinuosa. Gradient in across-leaf curvature along the length of 3 randomly selected leaves

\section{DISCUSSION}

Observed changes in epiphyte species composition and abundance on leaves of the seagrasses Posidonia australis and $P$. sinuosa clearly indicate non-random spatial and temporal distribution of the epiphytic organisms. Both species had a greater abundance and a higher diversity of epiphytic organisms on the oldest leaf in the cluster and on the oldest section (apex) of all leaves examined. Many of the epiphytes are also more abundant on specific locations on the leaves; generally, epiphytic algae were more abundant near the leaf apex, whereas epiphytic invertebrates were more abundant near the leaf base. Similar trends in epiphyte distribution have been observed for Posidonia spp. by Horner (1987) and for Amphibolis griffithsii by Borowitzka et al. (1990).

With the exception of isolated occurrences of the coralline alga Metagoniolithon chara (Lamarck) Ducker, all the epiphytic algae and invertebrates found on Posidonia australis were also present on $P$. sinuosa. However, during March, a greater diversity of epiphytic algae and invertebrates was found on the leaves of $P$. sinuosa. It is likely that this is due to the greater surface area available for colonisation on the longer $P$. sinuosa leaves, as well as the more complex morphology of these leaves. The fact that $P$. sinuosa leaves have a longer life (Cambridge 1996) may also be a contributing factor.

Studies of the natural and artificial leaves showed that the encrusting coralline algae of the FosliellaPneophyllum complex are the primary leaf colonisers on both Posidonia species, and that they occur on all but the newly emergent leaf sections. This has also been observed on many other seagrass species such as
Amphibolis antarctica (Labillardiere) Sonder and Ascherson ex Ascherson (Bramwell \& Woelkerling 1984), A. griffithii (J. M. Black) den Hartog (Borowitzka et al. 1990), and Thalassia testudinum Banks ex König (Humm 1964). Among the invertebrates, the hydrozoan Plumularia compressa, Foraminiferan 1, and the polychaete Spirorbis sp. were the initial colonisers, although these organisms were much less abundant on the artificial leaves. These results confirm that, at least in the early stages of colonisation, seagrass leaves act as a 'neutral' substratum for the attachment of epiphytic organisms. The observations of Harlin (1973), Cattaneo \& Kalff (1979), Horner (1987) and Lethbridge et al. (1988), who compared epiphyte growth and distribution on natural and morphologically similar artificial substrata, support this finding. These authors also showed that continued exposure of artificial substrata to epiphyte propagules ultimately results in nearly identical patterns of epiphyte distribution to those occurring on the natural substrata within a time period equivalent to that of the average lifespan of the macrophyte host, therefore indicating that the apico-basal distribution of epiphytes is not due to any inherent properties of the seagrass leaf such as the production of antifouling compounds.

The outcome of selective settlement of larvae as well as different degrees of mortality on specific areas of the leaf surface may have had an effect on the pattern of distribution of epiphytic organisms observed in this study (Keough 1986, Mazella \& Russo 1989, Kaehler \& Hughes 1992). Many species of encrusting coralline algae (Melobesiaceae) are able to establish themselves where conditions are not favourable for most other species. It has been proposed that these rapidly growing species modify the seagrass leaf surface, creating more suitable substrata for other epiphytic algae (Ballantine 1979, Harlin 1980, Breitburg 1984). However, in this study most epiphytes were observed to attach directly onto the leaf epidermis and not the coralline algae. Thus, it seems unlikely that the crustose coralline algae had a strong influence on subsequent settlement and recruitment. Generally, the initial colonisers were still present in the older portions of the leaf, but they became less important in terms of relative abundance and dominance. Similar observations have been made on the seagrass Thalassia hemprichii (Ehrenberg) Ascherson (Heijs 1985b) and algal hosts (Ballantine 1979).

The progressive increases in the mean percentage cover and species diversity of the epiphytic algae as the leaves age has also been reported for Posidonia oceanica (L.) Délile (Van der Ben 1971, Borum 1987), Phyllospadix torreyi Watson (Willcocks 1982), Zostera marina L. (Jacobs et al. 1983), Heterozostera tasmanica (Martens ex Ascherson) den Hartog (Bulthuis \& 
Woelkerling 1983), Amphibolis antarctica (Bramwell \& Woelkerling 1984), A. griffithii (Borowitzka et al. 1990) and Thalassia hemprichii (Heijs 1985a). The time available for the accumulation of biomass is also regarded as an important factor in the establishment of zonation of epiphytic organisms on macrophyte hosts (e.g. Ballantine 1979, Borum 1987, Mazella \& Russo 1989). Significant differences in the species richness and coverage of epiphytic organisms on Posidonia leaves of different ages provide circumstantial evidence to support this hypothesis. However, studies using artificial seagrass leaves exposed for the same time suggest that relative position along the leaf is more important than the time available for biomass accumulation (Harlin 1973, Horner 1987, Borowitzka et al. 1990). Horner (1987) suggests that observed gradients in the distribution of epiphytic organisms are not a result of leaf growth or the time available for colonisation, but rather that they are due to gradients in physical factors which affect the growth rate of settled individuals.

Light, nutrients and current flow are the major environmental variables that universally affect seagrasses and their epiphyte communities (Short 1987, Borowitzka \& Lethbridge 1989). Competition for light plays an important role in structuring marine communities (e.g. Sand-Jensen 1977, Reed \& Foster 1984, Borum 1987), and there is circumstantial evidence to indicate that light is a primary factor influencing algal recruitment and growth. Epiphytic algae are exposed advantageously to light and nutrients and are less subject to sedimentation at the leaf apices as the leaves move back and forth with the current (Keough 1986, Borowitzka et al. 1990). Self shading, reported to exceed $90 \%$ by some workers (Borum \& Wium-Andersen 1980, Borum et al. 1984), also affects algal growth toward the leaf base more than competition for space by sessile animals (Sand-Jensen 1977, Borum 1987). On the other hand, nutrient exchange is increased through enhanced water movement near the leaf apex (Harlin 1975, Fonseca et al. 1982, Fonseca \& Kenworthy 1987. Horner 1987). This may explain why larger fleshy algae such as Ceramium spp., Champia zostericola, Laurencia spp. and Mychodea gracilaria were commonly found on the middle and apical sections of the leaves but rarely on the base.

By comparison, sessile, filter-feeding, epiphytic invertebrates were more abundant on the basal portions of the leaves, presumably as a result of these organisms being less able to compete for settlement space, as well as being outcompeted during the recruitment phase by rapidly growing epiphytic algae in regions of high light (Fletcher \& Day 1983, Borowitzka \& Lethbridge 1989). Lashing of the distal portions of the leaves and abrasion from adjacent leaves, as well as predation by mobile epiphytic organisms such as gastropods, are also detrimental to juvenile communities and to delicate and weakly attached organisms (Fletcher \& Day 1983, Keough 1986, Mazella \& Russo 1989). It is likely that these factors affect sensitive species, such as hydroids, restricting them to the basal regions of the seagrass leaves.

The across-leaf distribution of epiphytic organisms on both natural and artificial Posidonia leaves clearly indicates that epiphyte propagules initially settle at the leaf margins. Similar results showing a higher cover of epiphytes on leaf margins have been obtained for $P$. oceanica (Van der Ben 1971), Zostera marina (Harlin 1975, Jacobs et al. 1983) and Thalassia hemprichii (Heijs 1985a). Furthermore, Harlin (1980) reported that epiphytes on $Z$. marina growing in calm waters tended to concentrate near the margin of the leaf, while in stronger currents the face of the leaf was more heavily colonised.

The results with artificial seagrass leaves presented here show similar across-leaf distribution patterns and indicate water flow patterns over the leaf edges are important in determining epiphyte distribution. As water moves around obstacles, turbulent eddies are formed near the edges, reducing water velocity relative to laminar flow regions (Foster 1975). This reduction in velocity may initially enhance spore and larval settlement, while increased circulation due to turbulence results in enhanced nutrient renewal and waste removal rates which could increase the growth of the plants.

One interesting result of the present study is the observation that epiphyte distribution differs between the 2 sides of Posidonia sinuosa leaves. Since the epidermis and cuticle of Posidonia leaves are identical in structure on both surfaces (Cambridge \& Kuo 1979, Novak 1984), observed differences must be related to other factors, such as variation in water flow patterns or light. Water flowing over the $P$. sinuosa leaf surface remains longer in contact with the concave leaf surface than the convex surface, so that epiphyte propagules have more time to become attached. Luttenton \& Rada (1986) have also proposed that, under conditions of increased turbulence, immigrating propagules may be prevented from successfully attaching to a substratum. Turbulence may either limit or inhibit contact between propagules and substrata, thus preventing the formation of an adhesive bond by the cell or propagule. Reduced light at the concave surface may also be a contributing factor. In still water $P$. sinuosa leaves tend to lay so that the convex surfaces of the leaves face upwards, and this implies that the net irradiance received by the concave surfaces of the leaves would be less than that received by the convex surfaces.

The distribution of epiphytic organisms on the strongly curved artificial leaves made from PVC hos- 
ing confirmed that leaf curvature strongly influences epiphyte settlement, recruitment and growth. A]though no significant differences in species number between the 2 sides of these 'leaves' were found, a markedly greater number of epiphytic algae settled on the concave surface. The artificial seagrasses also illustrate the importance of substratum texture. The PVC leaf models had a very smooth surface compared to the flagging tape, and on the former the epiphytic organisms could not attach successfully at the tips, where water velocity is greatest. Thus the artificial leaves of flagging tape with its rough surface showed the same apico-basal distribution of epiphytic organisms as the seagrass (see also Horner 1987 and Lethbridge et al. 1988 for similar observations), whereas the smooth PVC artificial leaves had a higher number of epiphytic organisms near the base. The importance of roughness is also indicated by the observation that more epiphytes occurred along the central axis of the curved PVC leaves, which was slightly roughened in the process of bending these leaves.

Differences in the growth habits of Posidonia australis and $P$. sinuosa also provide further insight into why differences in epiphyte species richness and cover occur between the 2 Posidonia species. The leaf density in $P$. australis meadows is significantly less than that of $P$. sinuosa. Furthermore, the shorter and thicker leaves of $P$. australis are quite stiff and tend to stand almost upright, bending over only at the distal end of the leaf, whereas the long flexible leaves of $P$. sinuosa characteristically bend over closer to the ground so that the rows of leaves form a dense mat lying almost parallel to the substratum. The dye studies reported here show that the sparse but erect leaf canopy of $P$. australis reduces circulation beneath it to an extent where the dye diffuses slowly around the leaves, but not into the water column above the bed. On the other hand, the more flexible and densely packed leaves of $P$. sinuosa redirect water flow from within the leaf canopy to the canopy surface. Thus it is likely that propagules of epiphytic species are subject to wider dispersion in a meadow of $P$. sinuosa than in a meadow of $P$. australis.

The effects of grazing, especially by molluscs, on the distribution of epiphytes cannot be ignored (Edgar 1990, Kendrick \& Burt 1997); however, we observed very few grazing scars on our leaves, suggesting that such grazing is not a major factor affecting the distribution of epiphytes.

While similar patterns of epiphyte distribution along the leaves of both species were found at both sampling times, there were seasonal differences. During autumn (i.e. April to May), massive shedding of Posidonia leaves occurs. This generally leaves $P$. australis plants bearing only 1 mature and 1 newly emergent leaf, and
$P$ sinuosa plants with 1 mature leaf only (Horner 1987. Trautman unpubl.). The abscission of these older leaves, which carry the heaviest epiphyte load, leads to a substantial decrease in the abundance and diversity of epiphytic organisms so that only initial colonising species and small individual macroalgae are observed on the remaining 'younger' leaves. Similar seasonal differences were obtained by Kendrick \& Burt (1997) on P. sinuosa, by Heijs (1985b), May et al. (1978) Jacobs et al. (1983) with other seagrasses, and by Whittick (1983) on the stipe of Laminaria hyperborea (Gunn.) Foslie.

During early autumn many species of epiphytic algae present on the leaves of Posidonia sinuosa were absent from the leaves of $P$. australis. However, during winter both Posidonia species had almost the same range of epiphytic algae, although the overall species numbers were reduced. By contrast, no marked change between seasons was observed in the occurrence of epiphytic invertebrates. Instead, a marked increase in the numbers of erect colonies of hydrozoans was found in winter, possibly due to reduced competition for space between these species and the epiphytic algae.

Increased turbulence resulting from storms over the winter may also remove or damage many erect or weakly attached species with increased lashing of the seagrass leaves, Luttenton \& Rada (1986) found that epiphytic communities exposed to increased levels of turbulence, such as that produced by wind-generated waves, resemble those in early stages of colonisation and development.

In summary, the results presented here indicate that physical factors, especially water flow which affect settlement, recruitment and growth, are important causes of the non-random distribution of epiphytes on Posidonia, whereas leaf age and the time of the year affect epiphyte abundance and diversity.

Acknowledgements. We thank J. Huisman and R. Lethbridge for their help in the identification of the algal and invertebrate species respectively, $M$. van Keulen for help with the flow studies and J. Stoddart for loan of the underwater video camera. Thanks also to T. Brown, B. Wienecke and J. Nielson for their assistance in the field, and I. Bennett for help in the statistical analysis. This study was supported, in part, by a Murdoch University Special Research Grant to M.A.B. and R. C. Lethbridge.

\section{LITERATURE CITED}

Ballantine DL (1979) The distribution of algal epiphytes on macrophyte hosts offshore from La Parguera, Puerto Rico Bot Mar 22:207-111

Ballantine D, Humm HJ (1975) Benthic algae of the Anclote Estuary. I. Epiphytes of seagrass leaves. Fl Sci 38:150-162 Borowitzka MA, Lethbridge RC (1989) Seagrass epiphytes. In: Larkum AWD, McComb AJ, Shepherd SA (eds) Sea- 
grasses: with special reference to the Australasian region Elsevier/North Holland. Amsterdam, p 458-499

Borowitzka MA, Lethbridge RC, Charlton L (1990) Species richness, spatial distribution and colonisation pattern of algal and invertebrate epiphytes on the seagrass Amphibolis griffithii. Mar Ecol Prog Ser 64:281-291

Borum J (1987) Dynamics of epiphyton on eelgrass (Zostera marina) leaves: relative roles of algal growth, herbivory, and substratum turnover. Limnol Oceanogr 32:986-992

Borum J, Wium-Andersen S (1980) Biomass and production of epiphytes on eelgrass (Zostera marina L.) in the Oresund, Denmark. Ophelia Suppl I:57-64

Borum J, Kass H, Wium-Andersen S (1984) Biomass variation and autotrophic production of an epiphyte-macrophyte community in a coastal Danish area: II. Epiphyte species composition, biomass and production. Ophelia 23:165-179

Bramwell MD, Woelkerling WJ (1984) Studies on the distribution of Pneophyllum-Fosliella plants (Corallinaceae, Rhodophyta) on leaves of the seagrass Amphibolis antarctica (Cymodoceaceae). Aust J Bot 32:131-137

Breitburg DL (1984) Residual effects of grazing: inhibition of competitor recruitment by encrusting coralline algae Ecology 65:1136-1143

Bulthuis DA, Woelkerling WJ (1983) Biomass accumulation and shading effects of epiphytes on leaves of the seagrass, Heterozostera tasmanica, in Victoria, Australia. Aquat Bot 16:137-148

Cambridge ML (1996) Is habitat separation between two species of Posidonia from Western Australia due to differences in nutrient use efficiency? In: Kuo J, Phillips RC, Walker DI, Kirkman H (eds) Seagrass biology. University of Western Australia, Perth, p 173-180

Cambridge ML, Kuo J (1979) Two new species of seagrasses from Australia, Posidonia sinuosa and P. angustifolia (Posidoniaceae). Aquat Bot 6:307-328

Cambridge ML, Chiffings AW, Brittan C, More L, McComb, AJ (1986) The loss of seagrass in Cockburn Sound, Western Australia. I1. Possible causes of seagrass decline. Aquat Bot 24:269-285

Cattaneo A, Kalff J (1979) Primary production of algae growing on natural and artificial aquatic plants: a study of interactions between epiphytes and their substrate. Limnol Oceanogr 24:1031-1037

Edgar GJ (1.990) Population regulation, population dynamics and competition amongst mobile epifauna associated with seagrass. J Exp Mar Biol Ecol 144:205-234

Fletcher WJ, Day RW (1983) The distribution of epifauna on Ecklonia radiata (C. Agardh) J. Agardh and the effect of disturbance. J Exp Mar Biol Ecol 71:205-220

Fonseca MS, Kenworthy WJ (1987) Effect of current on photosynthesis and distribution of seagrasses. Aquat Bot 27: $59-78$

Fonseca MS, Fisher JS, Zieman JC, Thayer GW (1982) Influence of the seagrass, Zostera marina L. on current flow. Estuar Coast Shelf Sci 15:351-364

Foster MS (1975) Regulation of algal community development in Macrocystis pyrifera forest. Mar Biol 32:331-342

Harlin MM (1973) 'Obligate' algal epiphyte, Smithora naiadum, grows on a synthetic substrate. J Phycol 9: $230-232$

Harlin MM (1975) Epiphyte-host relations in seagrass communities. Aquat Bot 1:125-131

Harlin MM (1980) Seagrass epiphytes. In: Phillips RC, McRoy CP (eds) Handbook of seagrass biology. Garland STPM Press, New York, p 117-151

Heijs FML (1984) Annual biomass and production of epiphytes in three monospecific seagrass communities of
Thalassia hemprichii (Ehrenb.) Aschers. Aquat Bot 20: 195-218

Heijs FML (1985a) The seasonal distribution and community structure of the epiphytic algae on Thalassia hemprichii (Ehrenb.) Aschers. from Papua New Guinea. Aquat Bot $21: 295-324$

Heijs FML (1985b) Some structural and functional aspects of the epiphytic component of four seagrass species (Cymodoceoideae) from Papua New Guinea. Aquat Bot 23 $225-247$

Hill MO (1979) TWINSPAN: a FORTRAN program for arranging multivariate data in an ordered two-way table by classification of the individuals and attributes. Section of Ecology and Systematics, Cornell University, Ithaca, NY

Horner SMJ (1987) Similarity of epiphyte biomass distribution on Posidonia and artificial seagrass leaves. Aquat Bot 27: $159-167$

Humm HJ (1964) Epiphytes of the seagrass, Thalassia testudinum, in Florida. Bull Mar Sci Gulf Caribb 14:306-341

Jacobs RPWM, Hermelink PM, Van Geel G (1983) Epiphytic algae on eelgrass at Roscoff, France. Aquat Bot 15: $157-173$

Kaehler S, Hughes RG (1992) The distributions and growth patterns of 3 epiphytic hydroids on the Caribbean seagrass Thalassia testudinum. Bull Mar Sci 51:329-336

Kendrick GA, Burt JS (1997) Seasonal changes in epiphytic macro-algae assemblages between offshore exposed and inshore protected Posidonia sinuosa Cambridge et Kuo seagrass meadows, Western Australia. Bot Mar 40:77-86

Keough MJ (1986) The distribution of a bryozoan on seagrass blades: settlement, growth and mortality. Ecology 67 : 846-857

Kershaw KA (1973) Quantitative and dynamic plant ecology Butler and Tanner Ltd, London

Lethbridge RC, Borowitzka MA, Benjamin K (1988) The development of an artificial Amphibolis-like seagrass of complex morphology and preliminary data on its colonisation by epiphytes. Aquat Bot 31:153-168

Luttendon MR, Rada RG (1986) Effects of disturbance on epiphytic community architecture. J Phycol 22:320-326

May $V$ (1982) The use of epiphytic algae to indicate environmental changes. Aust J Ecol 7:101-102

May V, Collins AJ, Collett LC (1.978) A comparative study of epiphytic algal communities on two common seagrasses in eastern Australia. Aust J Ecol 3:91-104

Mazella L, Alberte RS (1986) Light adaptation and the role of autotrophic epiphytes in primary production on the temperate seagrass, Zostera marina L. J Exp Mar Biol Ecol $100: 165-180$

Mazella L, Russo GF (1989) Grazing effect of two Gibbula species (Mollusca, Archaeogastropoda) on the epiphytic community of Posidonia oceanica leaves. Aquat Bot 35 : $357-373$

Moncreiff CA, Sultivan MJ, Daehnick AE (1992) Primary production dynamics in seagrass beds of Mississippi Soundthe contributions of seagrass, epiphytic algae, sand microflora, and phytoplankton. Mar Ecol Prog Ser 87 . $161-171$

Novak R (1984) A study in ultra-ecology: microorganisms on the seagrass Posidonia oceanica (L.) Délile. PSZN I: Mar Ecol 5:143-190

Pansini M, Pronzato R (1985) Distribution and ecology of epiphytic porifera in two Posidonia oceanica (L.) Délile meadows of the Ligurian and Tyrrhenian Sea. PSZN I: Mar Ecol 6: $1-11$

Penhale PA (1977) Macrophyte-epiphyte biomass and pro- 
ductivity in an eelgrass (Zostera marina L.) community. J Exp Mar Biol Ecol 26:211-224

Reed DC, Foster MS (1984) The effects of canopy shading on algal recruitment and growth in a giant kelp forest. Ecology 65:937-948

Sand-Jensen KA.J (1977) Effect of epiphytes on eelgrass photosynthesis. Aquat Bot 3:55-63

Short FT (1987) Introduction to 'Environmental impacts on seagrass' Aquat Bot 27:1-2

Van der Ben D (1971) Les épiphytes des feuilles de Posidonia oceanica Délile sur les côtes françaises de la Méditerranée. Inst R Sci Nat Belg Mem 168:1-101

Editorial responsibility: Otto Kinne (Editor),

Oldendorf/Luhe, Germany
Walker DI, Woelkerling WJ (1988) Quantitative study of sediment contribution by epiphytic coralline red algae in seagrass meadows in Shark Bay, Western Australia. Mar Ecol Prog Ser 43:71-77

Whittick A (1983) Spatial and temporal distribution of dominant epiphytes on the stipes of Laminaria hyperborea (Gunn.) Fosl. (Phaeophyta: Laminariales) in SE Scotland. J Exp Mar Biol Ecol 73:1-10

Willcocks PA (1982) Colonization and distribution of the red algal epiphytes Melobesia mediocris and Smithora naiadum on the seagrass Phyllospadix torreyi. Aquat Bot $12: 365-373$

Submitted: May 25, 1998; Accepted: November 18, 1998 Proofs received from author(s): March 15, 1999 